\title{
Repeated intravenous thrombolysis in recurrent ischemic stroke: a case report and review from the literature
}

\author{
Anita Arsovska ${ }^{1}$, Marija Babunovska ${ }^{1}$, Katina Aleksovska ${ }^{2}$ \\ ${ }^{1}$ University Clinic of Neurology, Medical Faculty, "University Ss Cyril and Methodius", Skopje, North Macedonia \\ ${ }^{2}$ University Clinic of Neurology, Skopje, North Macedonia
}

OPEN ACCESS

Correspondence: Anita Arsovska, MD, PhD anita70mk@yahoo.com orcid.org/0000-0003-1927-9614

This article was submitted to RAD CASA - Medical Sciences as the original article

Conflict of Interest Statement: The authors declare that the research was conducted in the absence of any commercial or financial relationships commercial or financial relationships conflict of interest.

Received: 20 November 2020 Accepted: 4 December 2020 Published: 28 December 2020

Citation:

Arsovska A, Babunovska M, Aleksovska K. Repeated intravenous thrombolysis in recurrent ischemic troke: a case report and review from the literature

RAD CASA - Medical Sciences. $544=52-53$ (2020): 78-83 DOI: https://dx.doi.org/10.21857/ m16wjcero9

Copyright (C) 2020 Arsovska A, Babunovska M, Aleksovska K. This is an open-access article distributed under open-access article distributed under the terms of the Creative Commons
Attribution License (CC BY). The use, Attribution License (CC BY). The use,
distribution or reproduction in other distribution or reproduction in other
forums is permitted, provided the original author(s) and the copyright owners(s) are credited and that the original publication in this journal is cited, in accordance whit accepted adacemic practice. No use, distribution or reproduction is permitted which does not comply with these terms.

\begin{abstract}
Background

Recurrent strokes occur in $25 \%$ of the cases during the first 5 years after the initial event. Each recurrent stroke increases the risk for severe disability and mortality. Intravenous thrombolysis (IVT) with recombinant tissue plasminogen activator ( $\mathrm{rtPA}$ ) is one of the therapeutic options when secondary prevention is not efficient and recurrent stroke occurs.
\end{abstract}

Aim

Aim of this paper is to present the first ever case of repeated IVT with rtPA in a female patient with recurrent stroke, hospitalized at the Department for Urgent Neurology, University Clinic of Neurology in Skopje, North Macedonia with a review from the literature.

Case presentation

A 59 years old female patient was admitted due to acute onset of motor and sensory dysphasia and right-sided hemiplegia. The symptoms occurred 1,5 hours before admission. Urgent computed tomography (CT) of the brain showed chronic cerebral infarction in the left and parietal regions, which causing traction of the left lateral ventricle. The patient experienced her first ischemic stroke 2,5 years ago and she was treated with IVT at the time. At the second hospital admission, the patient was conscious, with vital signs and urgent laboratory parameters within normal range. NIHSS score was 13 and a decision for IVT treatment was made. During the application of rtPA, her vital parameters were stable and no side effects were observed. Neurological status of the patient also improved, with NIHSS of 7 at the end of the IVT treatment. Control CT scan performed 24 hours after was without any new lesions. The patient was discharged in a stable condition, with a NIHSS of 4 and mRS of 3 .

Conclusion

Repeated IVT in recurrent stroke is feasible and safe in carefully selected patients. Assessment of risk factors and neuroimaging are crucial when deciding on repeated IVT.

KEYWORDS: recurrent stroke, repeated intravenous thrombolysis, recombinant tissue plasminogen activator

\section{SAŽETAK}

PONOVLJENA INTRAVENSKA TROMBOLIZA KOD BOLESNIKA S RECIDIVOM ISHEMIJSKOG MOŽDANOG UDARA PRIKAZ SLUČAJA I PRIKAZ IZ LITERATURE

Uvod

Recidivi moždanih udara javljaju se u $25 \%$ slučajeva tijekom prvih 5 godina nakon inicijalnog događaja. Svaki ponovljeni moždani udar povećava rizik za težu onesposobljenost i smrtnost. Intra- 
venska tromboliza (IVT) s rekombinantnim tkivnim aktivatorom plazminogena (rtPA) jedna je od terapijskih mogućnosti u slučajevima kada sekundarna prevencija moždanog udara nije učinkovita te nastupi recidiv moždanog udara.

Prikaz slučaja

Predstavljamo prvi slučaj na našoj klinici s recidivom moždanim udarom liječenim ponovljenim IVT. 59-godišnja pacijentica primljena je zbog akutne pojave senzomotore disfazije i desne hemiplegije. Simptomi su se javili 1,5 sata prije prijema u bolnicu. Hitna kompjuterizirana tomografija (CT) mozga nije pokazala nove lezije, dok su se prikazale malacijske lezije u lijevoj frontalnoj i parijetalnoj regiji uzrokujući retraktilne promjene na lijevu lateralnu moždanu klijetku. Pacijentica je prvi ishemijski moždani udar doživjela prije 2,5 godine i tada je liječena IVT-om. Pri ovom prijemu u bolnicu, pacijentica je bila pri svijesti, s vitalnim znakovima i hitnim laboratorijskim parametrima unutar normalnih granica. NIHSS rezultat je bio 13 i donesena je odluka o IVT liječenju. Tijekom primjene rtPA, vitalni su joj parametri bili stabilni i nisu primijećene nuspojave. Neurološki status pacijenta također se poboljšao na NIHSS od 7 na kraju IVT-a. Kontrolno CT snimnanje mozga nakon 24 sata nije pokazalo novih lezija. Pacijentica je otpušten u stabilnom stanju, s NIHSS 4 i mRS 3.

Zaključak

Ponovljeni IVT kod ponovljenog moždanog udara izvediv je i siguran kod pažljivo odabranih bolesnika. Procjena čimbenika rizika i nalaz neuoslikovnih metoda prikaza mozga presudni su pri odluci o ponovljenoj primjeni IVT-a.

KLJUČNE RIJEČI: recidivirajući moždani udar; ponovljena tromboliza; rekombinantni tkivni aktivator plazminogena.

\section{INTRODUCTION}

Acute ischemic stroke (AIS) is caused by thrombotic or embolic occlusion of a cerebral artery, resulting in a corresponding loss/ deterioration of neurologic functions. According to the World Health Organization (WHO), 15 million people in the world suffer from stroke each year. Of them, 5 million have lethal outcome, and another 5 million are left permanently disabled ${ }^{1}$. Men have higher risk for stroke than women, with an incidence of 62.8 per 100,000 , and a mortality rate of $26.3 \%$. Women have a stroke incidence of 59 per 100,000 and a mortality rate of $39.2 \%$. Risk of stroke increases with age, and $75 \%$ of all strokes occur in patients older than 64 years.

According to the guidelines from the European Stroke Organization (ESO) and the American Heart and Stroke Association (AHA/ASA), intravenous thrombolysis (IVT) with recombinant tissue-type plasminogen activator (rtPA) is included therapy for acute ischemic stroke in selected patients, in a time window of 3-4,5 hours after symptom onset is ${ }^{2,3}$.

The treatment after IVT consists of optimal strategy for secondary stroke prevention. However, recurrent strokes occur in 25\% of the cases during the first 5 years after the initial event. Each recurrent stroke increases the risk for severe disability and mortality ${ }^{4}$. IVT is one of the therapeutic options when secondary prevention is not efficient and recurrent stroke occurs. However, the application raises certain concerns regarding its short-term and long-term side effects. Complications of intravenous rt-PA for acute ischemic stroke are commonly related to hemorrhage, arterial reocclusion, anaphylaxis, or reperfusion damage. Aim of this paper is to present the first ever case of repeated IVT with rtPA in a female patient with recurrent stroke, hospitalized at the Department for Urgent Neurology, University Clinic of Neurology in Skopje, North Macedonia with a review from the literature.

\section{CASE PRESENTATION}

We present a case of a 59 years old female patient, who was admitted at the Department for Urgent Neurology, University Clinic of Neurology, due to acute onset of motor and sensory dysphasia and right-sided hemiplegia (facio-brachial type). The symptoms occurred 1,5 hours before admission. Beside well controlled hypertension, the patient did not have any vascular risk factors. Urgent computed tomography (CT) of the brain showed chronic cerebral infarction in the left and parietal regions, which causing traction of the left lateral ventricle. (Figure 1).

In fact, the patient experienced her first ischemic stroke 2,5 years ago and she was treated with IVT at the time. After the first hospitalization, the patient was dismissed with dual antiplatelet therapy (ASA and clopidogrel), statin (rosuvastatin) and antihypertensive therapy. After 3 weeks, clopidogrel was stopped and the patient continued monotherapy with ASA. In the following period after the first stroke, the patient recovered almost 

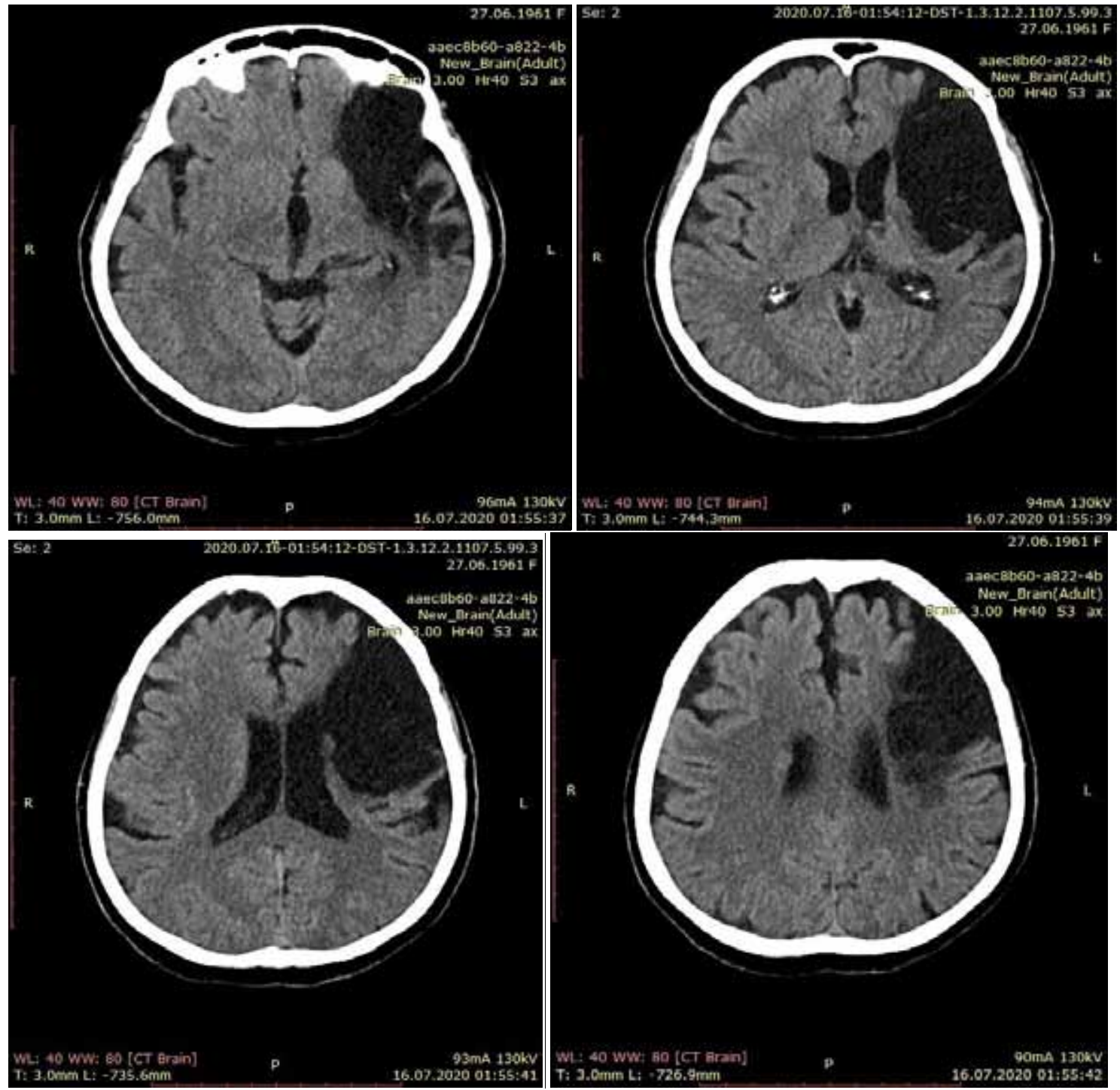

Figure 1. First CT scan with large postapoplectic sequela in the left frontal and parietal region

completely, with residual right sided hemiparesis of mild degree (with National Institute of Health Stroke Scale (NIHSS) of 4 and modified Rankin Score (mRS) of 2).

At the second hospital admission, the patient was conscious, with vital signs (blood pressure 125/75 $\mathrm{mmHg}$; heart rate- rhythmic, frequency 66/minute) and urgent laboratory parameters (glycemia 5,7 mmol/L, platelets $28310 \wedge 9 / \mathrm{L}$ ) within normal range. NIHSS score was 13 and therefore, a decision for IVT treatment was made, taken into consideration that the patient fulfilled the inclusion criteria. With a door-to-needle (DTN) time of 60 minutes, Actilyse was given according the protocol, in a therapeutical dose of $63 \mathrm{ml}$. During the application of Actilyse, her vital parameters were stable and no side effects were observed. Neurological status of the patient also improved, with NIHSS of 7 at the end of the IVT treatment.

Control CT scan performed 24 hours after was without any new lesions (Figure 2). Other laboratory results (blood and urine analysis, D-dimers and coagulation factors) obtained during the hospitalization were in normal range. Color duplex sonography of the extracranial carotid and vertebral arteries was normal. The next day after IVT treatment, antiplatelet (ASA), prophylactic anticoagulation (LMWH) and statin (atorvastatin) therapy was initiated, as well as antihypertensive (lisinopril), anxiolytic (diazepam) and physical therapy.

Her neurological status furtherly improved and after 13 days of hospitalization the patient was dismissed in a stable condition, with a NIHSS of 4 and $\mathrm{mRS}$ of 3 . We recommended dual antiplatelet therapy (combination of clopidogrel and cilostazol for the duration of 3 weeks, and than only clopidogrel), statin (rosuvastatin) and antihypertensive therapy (ACE inhibitor). We did not recommend ASA because the patient experienced recurrent stroke despite regular previous treatment with this medication. On follow-up control examinations in the next 3 months, the patient was stable with only mild residual neurologic deficit. 

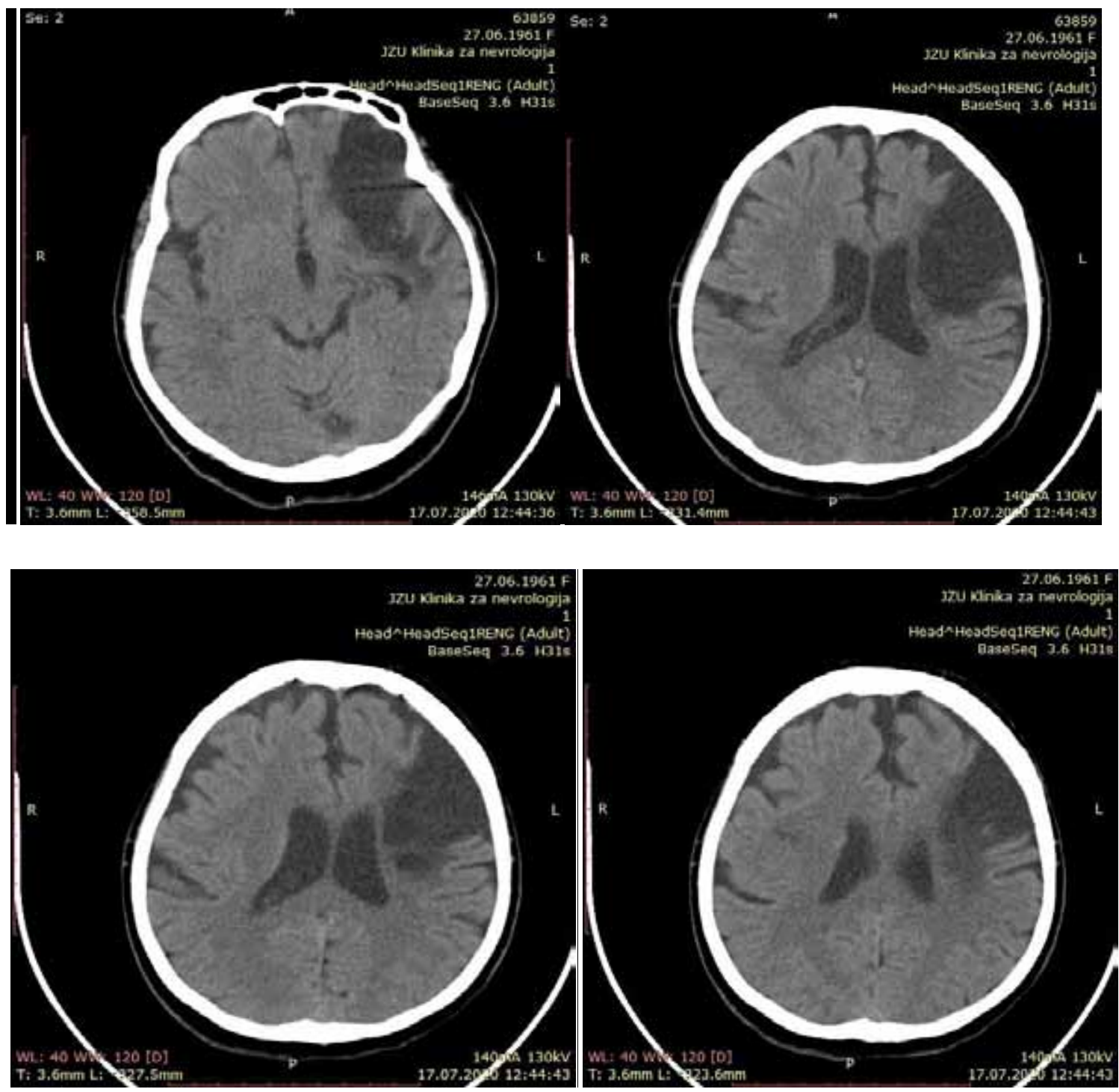

Figure 2. Control CT of the brain that did not show any new lesions, only large postapoplectic sequela in the left frontal and parietal region

\section{DISCUSSION}

This patient was the first ever case at our clinic with recurrent stroke treated with repeated IVT. In the period 2015-2020 there was a total of 170 patients treated with IVT at the clinic, an average of $9 \%$ out of the total number of stroke patients.

Data from the literature show limited experience regarding repeated thrombolytic treatments in stroke patients. This procedure can be considered in a stroke patient if the initial IVT attempt has been unsuccessful or if the recurrent stroke has occurred 3 months after the first event ${ }^{2,5}$.

The following papers have described repeated IVT use in recurrent stroke occurring more than 3 months after the initial event. Arsava and Topcioglu described de-novo thrombolysis for recurrent stroke in a patient with prior history of thrombolysis ${ }^{6}$. A 67-year-old male with prior history of atrial fibrillation was admitted with acute onset of aphasia and he was treated by IVT. Approximately 2 years later he presented with left-sided weak- ness, and was again treated with intravenous rtPA. The patient responded favorably to thrombolytics on both occasions, without significant complications and with satisfactory recovery. Their study, although reflecting experience from a single case, highlights that repeated administration of intravenous rtPA is well tolerated in stroke patients with late recurrences and previous history of thrombolysis.

Yoo et al. investigated patients with acute ischemic stroke who had received thrombolytic treatments for a period of 10 years ${ }^{7}$. Of the 437 patients who received thrombolytic treatments, only 7 underwent repeated thrombolysis (1.6\%). The median age at the time of repeated thrombolytic therapy was 71 years old; 4 of the patients were female. All patients had 1 or more potential sources of cardiac embolism. Recanalization was achieved in all patients, in both the first and the second thrombolysis. No symptomatic ICH occurred after repeated thrombolytic treatments. Five patients $(71.4 \%)$ showed good outcomes at 3 months. The authors concluded that 
among patients who experience recurrent acute ischemic stroke, thrombolytic therapy could be considered even if the patient has had previous thrombolytic treatments.

Cappellari et al. described 8 patients with repeated IVT after recurrent stroke among 615 consecutive stroke patients who received IVT at their Stroke Unit and 22 cases of IV re-thrombolysed patients extracted for the literature review of case reports and case series ${ }^{8}$. After excluding the 6 patients treated with endovascular procedures, they included in the analyses 21 patients for which they had data on pre-stroke functional status and baseline neurological severity for each stroke event and post-treatment functional status for each IVT. They compared second $(\mathrm{n}=21)$ and third $(\mathrm{n}=3)$ IVT treatments with first IVT treatments $(\mathrm{n}=21)$. Also, they compared IVT re-treatments $\leq 3$ months from previous IVT thrombolysis $(n=10)$ with those N3 months $(n=14)$. No significant differences in the rate of $\mathrm{ICH}$ with neurological deterioration, mortality and restitution of the pre-existing functional status were observed in the comparative analyses. The authors emphasized that repeated IVT may be safe and effective when recurrent stroke occurs after a period of complete neurologic regression lasting at least $24 \mathrm{~h}$ or minor disability ( $\mathrm{mRS}$ score $\leq 2)$ lasting at least 3 months since the previous stroke.

Papers that described use of repeated IVT in patients with early recurrent stroke have also been published.

Ashrafi et al. described a case report with a secondary stroke after thrombolytic administration ${ }^{9}$. The patient was a 68 -year-old man with the history of uncontrolled hypertension and diabetes mellitus presented with acute ischemic stroke in the territory of vertebrobasilar system to the emergency department. Atrial fibrillation (AF) rhythm, hyperglycemia and uncontrolled hypertension were recorded on admission. Echocardiography performed before thrombolysis, did not identify any embolic sources. Five hours after intravenous injection of rtPA, the patient became comatose and developed a recurrent infarction in the territory of right middle cerebral artery (MCA). The authors concluded that thrombolysis therapy in patients with the risk factors of recurrent stroke, must be done with more preparation and readiness for concurrent processing. Regardless of normal trans-thoracic echocardiography, in patients with AF rhythm, transesophageal echocardiography may be helpful.

Wu et al. conducted a systemic literature review in PubMed up to December, $2015^{10}$. A total of 15 studies involving 57 cases and 61 randomized trials (RTs) were collected. The median age of the patients was 73 at the first event, the median time interval was 225 days and $45.9 \%$ were female. High severity and worse functional outcome were observed in the RT group, but the difference of ICHs from 2 events did not reach statistical significance. More ICHs occurred in RTs with prior stroke within last 30 days than those in chronic stroke phase in a subgroup analysis $(25.0-4.9 \%, \mathrm{p}=0.018)$. Only NIHSS was significantly associated with a good functional outcome (OR 0.921, 95\%
CI 0.857-0.990) and ICH (OR 1.177, 95\% CI 1.031-1.344) in the logistic regression analysis. Their literature review indicated that baseline stroke severity was the main predictor of the functional outcome and ICH after RT, similar to the results of the first thrombolysis in AIS. The accumulation of disability (measured by NIHSS) in recurrent stroke could have contributed to the worse prognosis after RT.

Kahles et al. reported the largest case series of repeated IVT in early recurrent stroke (ERS) ${ }^{11}$. They identified 19 subjects with repeated IVT in ERS. Mean age was $68 \pm 12$ years, and $37 \%$ of them were female. Median interthrombolysis interval was 30 days (interquartile range, 13-50). Functional independence (modified Rankin scale score $\leq 2$ ) was achieved in $79 \%$ of patients after the first and in $47.4 \%$ after repeated IV tissue-type plasminogen activator, respectively. There was no symptomatic ICH. Median final infarct volume after the first IVT was 1.5 $\mathrm{cm} 3$ (interquartile range, $0.5-3.1$ ). The authors concluded that patients with small infarct volumes and robust clinical improvement might be considered for repeated IVT within 3 months. Caruso et al described a case report with early repeated thrombolysis ${ }^{12}$. They presented a 59-year-old man with stroke and NIHSS of 16, 10 days after a previous stroke. Brain computed tomography (CT) showed a previous hypodensity with $4 \mathrm{~cm} 3$ volume. Angio-CT highlighted the left middle cerebral artery and left internal carotid occlusion. Perfusion CT showed small deep core and large penumbra. The patient underwent intravenous rtPA. After 24 hours, the NIHSS was 7, and CT scan showed an acute ischemic lesion in the left basal ganglia area and frontal lobe without hemorrhagic transformation. The authors concluded that this case report suggests that further randomized studies may evaluate whether repeated intravenous rtPA may be safe and effective in ERS occurring shortly after a previous stroke when patients experience a period of complete neurological regression, minor disability, and a small infarct volume.

Sarmiento et al. described the safety and efficacy of repeated thrombolysis with alteplase in early recurrent ischemic stroke in a systematic review ${ }^{13}$. They included ten articles with 33 patients in total. One patient developed symptomatic ICH after the second reperfusion attempt and subsequently died from pneumonia. Another died from spontaneous rupture of previously unidentified infrarenal aortic aneurysm. Six of the 13 patients with available follow-up data had good clinical outcomes (mRS $0-2)$. There were no allergic reactions and other drug-related adverse events noted. The authors concluded that repeated IV alteplase can be safe and efficacious in patients who have early recurrent ischemic stroke.

Regarding the early post-IVT treatment of our patients, we recommended dual antiplatelet therapy which included clopidogrel and cilostazol. The combination of cilostazol with ASA or clopidogrel showed a reduced incidence of ischaemic stroke recurrence and a similar risk of severe or life-threatening bleed- 
ing compared with treatment with ASA or clopidogrel alone in patients at high risk for recurrent ischaemic stroke ${ }^{14}$. Although majority of the clinical trials have been performed in Asian population ${ }^{15}$, we speculated that the patient had a clinical resistance to ASA and recommended cilostazol instead.

We also recommended anxiolytic therapy with diazepam, which has been shown to have benefit in cardioembolic infarct patients and is safe in acute ischemic stroke ${ }^{16}$.

The strengths of our case report are:

1. This is the first ever successful application of repeated IVT in a recurrent stroke at our clinic. The decision was not easy, taken into account the large chronic ischemic lesion on the CT scan.

2. The combination of dual antiplatelet therapy with clopidogrel and cilostazol, although unusual for Caucasian population has shown efficacy and safety in our patient.
The limitation of our case report are:

1. We could not define the exact cause of the recurrent stroke, but speculated that it occurred due to clinical resistance to ASA.

\section{CONCLUSION}

Our case report case report satisfies current trends in treatment of recurrent stroke. Repeated IVT in recurrent stroke is feasible and safe in carefully selected patients. Assessment of risk factors and neuroimaging scans is crucial when deciding on repeated IVT. There is a need for larger studies, defined inclusion and exclusion criteria and updated protocol in order to minimize side-effects of the repeated IVT in recurrent stroke patients.

\section{LITERATURE:}

1. MacKay J, Mensah GA. World Health Organization. Global Burden of Stroke. The Atlas of Heart Disease and Stroke. Available at http:// www.who.int/cardiovascular_diseases/en/cvd_atlas_15_burden_stroke. pdf.

2. Ringleb A, Bousser M-G, Ford G, Bath P, Brainin M, Caso V, et al. Guidelines for management of ischaemic stroke and transient ischaemic attack. Cerebrovasc Dis. 2008;25:457-507.

3. 2018 Guidelines for the Early Management of Patients With Acute Ischemic Stroke: A Guideline for Healthcare Professionals From the American Heart Association/American Stroke Association. Stroke 2018;49:e46-e110.

4. Hardie K, Hankey GJ, Jamrozik K, Broadhurst RJ, Anderson C. Tenyear risk of first recurrent stroke and disability after first-ever stroke in the Perth Community Stroke Study. Stroke 2004;35:731-5.

5. Jauch EC, Saver JL, Adams HP Jr, Bruno A, Connors JJ, Demaerschalk BM, et al; American Heart Association Stroke Council; Council on Cardiovascular Nursing; Council on Peripheral Vascular Disease; Council on Clinical Cardiology. Guidelines for the early management of patients with acute ischemic stroke: a guideline for healthcare professionals from the American Heart Association/American Stroke Association. Stroke. 2013;44:870-947. doi: 10.1161/STR.0b013e318284056a. 6. Arsava EM, Topcuoglu MA. De-novo thrombolysis for recurrent stroke in a patient with prior history of thrombolysis. Blood Coagulation and Fibrinolysis 2010, 21:605-607

7. Yoo HS, Kim YD, Lee HS, et al. Repeated thrombolytic therapy in patients with recurrent acute ischemic stroke. J Stroke. 2013;15(3):182188. doi:10.5853/jos.2013.15.3.182

8. Cappellari M, Moretto G, Bovi P. Repeated intravenous thrombolysis after recurrent stroke. A case series and review of the literature. Journal of the Neurological Sciences 345-2014; 181-183
9. Ashrafi A, Baratloo A, Nasiri Z, Soleymani M, Asaadi S. Secondary Stroke After Thrombolytic Administration; A Case Report. Arch Neurosci. 2015 January; 2(1): e17315. DOI: 10.5812/archneurosci. 17315 10. Wu J, Huang Q, Ma Qing-feng. What Matters in the Results of Repeated Intravenous Thrombolysis for Recurrent Ischemic Stroke? Eur Neurol 2016;75:150-154

11. Kahles T, Mono ML, Heldner MR, Baumgartner RW, Sarikaya H, Luft A, Bohlhalter S, Traenka C, Engelter S, Kurka N, Köhrmann M, Curtze S, Michel P, Tatlisumak T, Nedeltchev K. Repeated Intravenous Thrombolysis for Early Recurrent Stroke: Challenging the Exclusion Criterion. Stroke. 2016;47:2133-2135. DOI: 10.1161

12. Caruso P, Furlanis G, Ridolfi M, Ajcevic M, Naccarato M, Manganotti P. Safety of Early Repeated Thrombolysis. A Case Report. The Neurologist 2019;24:143-145

13. Sarmiento RJC, Diestro JDB, Espiritu AI, San Jose MC. Safety and Efficacy of Repeated Thrombolysis with Alteplase in Early Recurrent Ischemic Stroke: A Systematic Review. Journal of Stroke and Cerebrovascular Diseases, Vol. 28, No. 10 (October), 2019: 104290

14. Toyoda K, Uchiyama S, Yamaguchi T, Easton JD, Kimura K et al. Dual antiplatelet therapy using cilostazol for secondary prevention in patients with high-risk ischaemic stroke in Japan: a multicentre, openlabel, randomised controlled trial.The Lancet Neurology, Vol 18, Issue 6, 2019:539-548.

15. McHutchison C, Blair GW, Appleton JP, et al. Cilostazol for Secondary Prevention of Stroke and Cognitive Decline: Systematic Review and Meta-Analysis. Stroke. 2020;51(8):2374-2385. doi:10.1161/ STROKEAHA.120.029454

16. Lodder J, van Raak L, Hilton A, Hardy E, Kessels A: Diazepam to Improve Acute Stroke Outcome: Results of the Early GABA-Ergic Activation Study In Stroke Trial. Cerebrovasc Dis 2006;21:120-127. doi: $10.1159 / 000090210$ 